\title{
O Barão e o Encilhamento: os Investimentos de José de Lacerda Guimarães na Economia Cafeeira Paulista (1885-1893)*
}

\section{The Baron and the Encilhamento: José de Lacerda Guimarães's Investments in the São Paulo's Coffee Economy (1885-1893)}

\author{
Gustavo Pereira da Silva ${ }^{a}$
}

\begin{abstract}
Resumo: O Encilhamento permanece como um controverso episódio na história econômica brasileira, sendo comumente seus efeitos negativos ligados à instabilidade macroeconômica que teria gerado. Todavia, há uma argumentação que realça os efeitos favoráveis à formação de empresas a partir dessas medidas econômicas. Nesse sentido, o artigo busca dar uma contribuição à compreensão dos efeitos do Encilhamento para a diversificação do capital no estado de São Paulo, considerando a escassez de estudos que atrelem diretamente o Encilhamento ao grande capital cafeeiro paulista. Para tanto, baseamo-nos na conta-corrente de José de Lacerda Guimarães (Barão de Arary) junto à casa comissária e exportadora J. F. de Lacerda E Cia., principal firma exportadora de café em Santos entre 1885-1886. Na contacorrente constam as operações de entradas de ações, que representam compras de papéis de empresas por parte do barão, operações que se tornaram maiores e mais diversificadas no período do Encilhamento (1889-1893).
\end{abstract}

Palavras-chave: Encilhamento. Barão de Arary. Diversificação.

\begin{abstract}
Encilhamento remains a controversial episode in Brazilian economic history, and its negatives are usually related to the macroeconomic instability it would have generated. However, there is an argument that highlights the favorable effects of the formation of companies on these economic measures. In this sense, the article seeks to contribute to the understanding of the effects of the Encilhamento for the diversification of capital in the state of São Paulo, considering the lack of studies that directly link the Encilhamento to the great coffee capital of São Paulo. To that end, we are based on the checking account of José de Lacerda Guimarães (Barão de Arary) in the house comissioner and exporter J. F. de Lacerda 8 Co., the main coffee exporting firm in Santos between 1885-1886. The checking account includes the operations of share inflows, which represent purchases of company shares by the Baron, operations that became larger and more diversified in the Encilhamento
\end{abstract} (1889-1893).

Keywords: Encilhamento. Barão de Arary. Diversification.

JEL Classification: N26; N56; N86.

O trabalho teve financiamento da Fundação de Amparo à Pesquisa do Estado de São Paulo (Fapesp) no processo 08/50917-0.

Universidade Federal de São Carlos (UFSCar), Departamento de Economia. Sorocaba, São Paulo, Brasil. 


\section{Introdução}

O Encilhamento é tido como uma crise financeira que se deu a partir de uma bolha especulativa concentrada na Bolsa de Valores do Rio de Janeiro no ano de 1891, quando na gestão da pasta da Fazenda encontrava-se Rui Barbosa. A polêmica em torno dessa crise permanece em virtude, por exemplo, de seus efeitos adversos em outras praças comerciais brasileiras, e mesmo de seu espraiamento por outros setores econômicos, como no caso das falências de empresas na praça fluminense naquele decênio. Tais efeitos seriam confrontados com o espocar de novas empresas possibilitado pela política econômica de Rui Barbosa, sendo que muitas dessas firmas permaneceriam durante os decênios posteriores e se tornariam grandes empresas nacionais. ${ }^{1}$

Essa crise se deu justamente em meio à transição político-econômica do Brasil, que, de um império, tornava-se uma república e de uma economia mercantil-escravista convertia-se em agroexportadora capitalista (MELLO, 2009, p. 63-82). Naquele momento, uma das questões-chave na seara econômica que opunha metalistas versus papelistas ${ }^{2}$ era a necessidade, ou não, de expansão monetária, dado que a quantidade de papel-moeda em circulação em 1889 era cinco por cento menor que em 1880 (SCHULZ, 2013, p. 75; FRANCO; LAGO, 2012, p. 179; LOBO, 1976, p. 264) ${ }^{3}$

O fenômeno do Encilhamento teria se iniciado ainda em junho de 1889, quando o Visconde de Ouro Preto, então ministro da Fazenda, pressionado a tomar medidas que contrabalançassem as perdas que os detentores de escravos tiveram com a abolição, agravadas pela necessidade de uma maior monetização -

$1 \quad$ Apesar de Bruzzi Curi (2015, p. 45-46) apontar a viragem ocorrida na visão sobre o período de Rui Barbosa como ministro da Fazenda (1889-1891), no sentido do reconhecimento da sua importância à formação de empresas no início da República, notamos que a caracterização negativa do Encilhamento ainda permanece, pois "A palavra Encilhamento passou a designar tanto a política econômica como a crise financeira do período. Embora três ministros tenham sido responsáveis pelo comando da economia no período - visconde de Ouro Preto, Rui Barbosa e barão de Lucena -, o estigma da crise ficou associado à gestão de Rui Barbosa. Sua política monetária expansionista é comumente apontada como responsável pelos descalabros financeiros do período [...]." (IPEA, 2011, p. 67).

2 Os metalistas (Joaquim Murtinho, Torres Homem, Francisco Belizário), calcados nas regras do sistema monetário do padrão-ouro, eram defensores da conversibilidade da moeda, o que limitava as emissões à existência de lastro metálico. Por sua vez, os papelistas (Visconde de Ouro Preto, Rui Barbosa, Souza Franco, discursando sobre a necessidade de bancos e crédito a uma economia em transição, admitiam um relaxamento nas regras de emissão monetária, que poderiam contemplar, em alguns casos, a emissão sem lastro (FONSECA; MOLLO, 2012, p. 215-218).

3 Segundo Furtado (2000, p. 175): "Entre 1880 e 1889, a quantidade de papel-moeda em circulação diminuiu de 216 para 197 mil contos, enquanto o valor do comércio exterior (importações + exportações) cresceu de 411 para 477 mil contos. Se se tem em conta que nesse período o sistema da escravidão foi substituído pelo do assalariado e que entraram no país cerca de 200 mil imigrantes, compreende-se facilmente a enorme adstringência de meios de pagamento que prevaleceu então. O sistema monetário de que dispunha o país demonstrava ser totalmente inadequado para uma economia baseada no trabalho assalariado". 
tendo em vista, por exemplo, os dispêndios com pagamentos de salários e, ao mesmo tempo, valendo-se de uma conjuntura de alta no preço internacional do café -, efetuou a regulamentação da lei bancária de 1888. A regulamentação previa a incorporação de um novo banco de emissão (Banco Nacional do Brasil), cujos papéis emitidos seriam lastreados em moeda e títulos do governo, sendo conversíveis ao câmbio de 27 pence por mil-réis, a paridade originária do ano de 1846 . Ademais, foram mantidos os empréstimos que o Tesouro fazia a alguns bancos à taxa de 4,5\%, com o compromisso desse crédito ser repassado aos agentes dos fazendeiros (comissários), geralmente a uma taxa de $6 \%$ ao ano, empréstimos que ficaram conhecidos como os auxílios à lavoura (FRANCO, 1989, p. 20; SCHULZ, 2013, p. 159).

Essa conjuntura de avanço creditício, sobretudo na praça do Rio de Janeiro - em que 14 bancos fluminenses foram fundados em 1889 - foi ainda mais estimulada com a chegada de Rui Barbosa ao primeiro ministério da Fazenda do período republicano (SCHULZ, 2013, p. 162). No dia 17 de janeiro, o ministro instituiu a lei bancária de 1890, criando três novos bancos de emissão (Norte, Centro e Nordeste), que foram autorizados a emitir até 450 mil contos de réis - valor que representava mais que o dobro do papel-moeda em circulação naquele momento - em papéis que seriam inconversíveis e lastreados em apólices da dívida pública. Junto à lei bancária, e no intuito de canalizar a expansão creditícia à constituição de novas firmas, Rui Barbosa instituiu os Decretos no 164 e 165, também em 17 de janeiro de 1890, que facilitavam a formação de sociedades anônimas, pois possibilitavam a essas empresas negociar suas ações apenas com a integralização de 10\% do capital subscrito pelos incorporadores - antes eram necessários subscrever 20\% do capital (LEVY, 1977, p. 180; LEVY, 1994, p. 127; FRANCO, 1989, p. 21; MARCONDES; HANLEY, 2010, p. 109; TANNURI, 1981, p. 65).

Os efeitos das medidas de Rui Barbosa foram imediatos na capital da República e outras praças. Com mais crédito, várias empresas foram constituídas por acionistas comuns, bem como por alguns bancos que, sendo universais, puderam, além de emitir moeda, ter uma carteira comercial, hipotecária, emprestar a longo prazo e, sobretudo, investir seu capital em papéis de empresas, como no caso de algumas têxteis fluminenses que tinham bancos como seus principais acionistas (LEVY, 1994, p. 150; FRANCO; LAGO, 2012, p. 180; HANLEY, 2005, p. 125). ${ }^{4}$

Todavia, naquele ano de 1890, a euforia que tomava conta do mercado acionário, com as pessoas lucrando com a venda de ações, sofreria uma reviravolta.

4 A condição de banco universal permitia a estas instituições realizarem: atividades de crédito comercial, como por exemplo, a provisão de empréstimos de curto prazo, descontos e câmbio; as atividades de crédito agrícola e hipotecário, como a concessão de financiamentos de longo prazo, garantidos por propriedades imobiliárias rurais ou urbanas, e adiantamentos contra colheitas futuras; crédito industrial para a construção de prédios, ferrovias, docas, melhorias portuárias, comunicações e atividades administrativas, como a propriedade e a operação de interesses industriais (MARCONDES; HANLEY, 2010, p. 105-113). 
A crise do banco Baring junto à Argentina gerou uma diminuição nos fluxos de capital estrangeiro que aportavam ao Brasil, implicando uma crise cambial agravada pelas emissões excessivas de moeda - de 1889 a 1894, a oferta de moeda aumentou 3,5 vezes (FRANCO; LAGO, 2012, p. 186). ${ }^{5}$ Rui Barbosa saiu da pasta da Fazenda em janeiro de 1891 e o legado de seu período à frente do ministério, na visão de seus críticos contemporâneos e recentes, seria a desvalorização cambial, o excesso de moeda e uma crise especulativa gerada pela formação de empresas frágeis na Bolsa de Rio de Janeiro - firmas que entrariam em falência nos anos posteriores -, efeitos imputados a uma suposta irresponsabilidade de Rui na condução das medidas econômicas (TAUNAY, 1923; ALMEIDA; CROCE, 2016; FURTADO, 2000, p. 174-177; TRINER; WANDSCHNEIDER, 2005, p. 205; TRINER, 2014, p. 157; SCHULZ, 2013, p. 173; PASSANANTI; GERBER, 2015, p. 39) 6 .

Entretanto, há na historiografia econômica aqueles que reconhecem a importância das medidas de Rui Barbosa para o estímulo às atividades econômicas nacionais, sobretudo à indústria, tanto que Fonseca (2004, p. 240) o trata como um dos precursores do desenvolvimentismo brasileiro, ao fomentar o crédito para além da agricultura. ${ }^{7}$ Para Stein (1979, p. 96-105), que concentra sua análise no setor têxtil, o período do Encilhamento gerou um ambiente favorável aos investimentos industriais ao flexibilizar as regras para a formação de empresas e gerar um volume grande de crédito para a aquisição de maquinário, sendo que o autor enxerga mesmo a desvalorização cambial, que se tornou alvo de crítica a Rui Barbosa, como mais um fator que promoveu a indústria nacional ao protegê-la dos similares estrangeiros.

Também baseando-se no têxtil, Fishlow (1972, p. 12-16) vê como positivos à indústria nacional os efeitos das medidas de Rui Barbosa, pois o aumento do crédito serviu para a formação de novas firmas têxteis algodoeiras no Rio de Janeiro, que surgiram quando o câmbio ainda estava valorizado (até junho de 1891), tendo facilitado a aquisição de maquinário, e, quando a taxa cambial iniciou forte queda, surgia o cenário de proteção às fábricas nacionais. Na mesma linha, seguem Lobo (1976, p. 269-271), Versiani (1980, p. 20) e Suzigan (2000, p. 50) ao admitirem

$5 \quad$ A dificuldade na venda dos papéis da Sociedade de Água e Esgoto de Buenos Aires foi o estopim da crise do banco Baring no mercado londrino em novembro de 1890 (LENZ, 2010, p. 229). Triner e Wandschneider (2005, p. 208-222) demonstram que, a partir daquele mês, houve aumento no prêmio de risco dos títulos soberanos do Brasil em Londres, indicando um contágio da crise argentina sobre o Brasil dado pela subida do custo de captação de recursos junto a Londres que, de modo geral, diminuiu na década de 1890.

6 A visão negativa das medidas adotadas por Rui Barbosa no início da República permanece em parte da historiografia econômica, como no texto de Almeida e Croce (2016, p. 33), que define: "O Encilhamento em si compreendeu um período de alta atividade especulativa na bolsa de valores, que acabou gerando uma escalada na taxa de juros, desvalorização cambial e, por fim, inflação. Esse período dura até o início dos anos 1890, mas os efeitos dessa crise só vão ser totalmente superados após a virada do século, com as liquidações bancárias".

7 Um balanço do debate historiográfico sobre a formação do desenvolvimentismo brasileiro na segunda metade do século XIX e na Primeira República encontra-se em Salomão (2017, p. 5-10). 
que no período do Encilhamento houve um intenso movimento de formação de empresas e ampliação da capacidade instalada das já existentes, evidenciado pelo aumento de 30\% das importações de maquinário industrial ao Brasil em 1890, cifra que, segundo Suzigan (2000), passou de $70 \%$ no ano seguinte. ${ }^{8}$

Segundo os intérpretes do capitalismo tardio, esse investimento em máquinas e equipamentos no início da República marcaria a gênese da indústria no estado de São Paulo. Silva (1995, p. 54-55), Mello (2009, p. 99-125) e Aureliano (1999, p. 30-54) calcam sua análise na relação café-indústria mostrando que, a princípio, essa unidade estimula a inversão industrial - concentrada nos bens de consumo assalariado - mas, a longo prazo, limita a formação de um setor de bens de capital. Para Cano (1981, p. 17-23), tratava-se de um vazamento de capital dentro do complexo cafeeiro paulista, ou seja, no momento que a atividade nuclear (produção cafeeira) atingia seu auge havia uma massa ainda maior de capitais a ser invertida nas atividades componentes (indústria, ferrovias, bancos, comércio de importação e exportação, empresas de serviços públicos). ${ }^{9}$

O investimento em outros elos do complexo cafeeiro se daria no intento de se desprender da lavoura - e de suas inconstâncias - como forma única de acumulação, o que possibilitava a esses indivíduos obter novas fontes de capitalização e inclusive aumentar a rentabilidade da propriedade agrícola, como no caso da constituição de uma ferrovia que transportasse de maneira mais eficiente o café (DEAN, 1971, p. 44-45). Esses fazendeiros e/ou imigrantes representavam o grande capital cafeeiro, ou seja, eram indivíduos que atuavam nos diversos ramos do complexo, além de, em muitos casos, terem participação na esfera política (PERISSINOTTO, 1994, p. 49; SILVA, 1995, p. 54).

Alguns trabalhos que se debruçaram sobre os inventários de indivíduos que residiram em municípios cafeicultores demonstram que a diversificação da riqueza se tornou uma tendência na segunda metade do século XIX, sobretudo entre os grandes proprietários e após a abolição. Em relação a Ribeirão Preto, o trabalho de Lopes (2007, p. 193) aponta que, na década de 1870 , quase $80 \%$ da riqueza inventariada era composta de imóveis $(52,1 \%$ do total) e escravos $(27,8 \%)$, enquanto o ativo - que englobava as ações e papéis de empresas, letras e hipotecas - representava apenas $10,3 \%$ do total da riqueza. Em um trabalho recente que aborda

8 É importante ressaltar que o estímulo à indústria também veio da política tarifária do início do período republicano, com a revisão das tarifas alfandegárias em janeiro de 1890 elevando os direitos de importação de diversos produtos e instituindo a cobrança de parte desses direitos em ouro (VILLELA, 1993, p. 68-86).

9 Entre 1889-1895, o Brasil era responsável por 58\% das exportações mundiais de café, sendo que esse é justamente o período em que o país auferiu os maiores valores com a exportação cafeeira no século XIX, com uma receita média anual de 20 milhões de libras esterlinas, que representavam 68\% das receitas gerais de exportações do Brasil entre 1889-1895. Em relação às zonas cafeeiras nacionais, o estado de São Paulo foi responsável pela produção de 60,5\% do café exportável pelo Brasil entre 1891-1900 (IBGE, 1990, p. 350; BACHA; GREENHILL, 1992, p. 351-355; CANO, 2002, p. 52). 
inventários da mesma localidade entre 1889-1900, Lopes (2016, p. 86) mostra que, em meio a um processo de ascensão dos cafezais ribeirão-pretanos e da urbanização, os imóveis passaram a representar $72,1 \%$ do total da riqueza, secundados pelos valores do ativo, que somavam $17,2 \%$ do total.

Em relação a Campinas, o artigo de Abrahão (2016, p. 305-311) indica que $45,5 \%$ do total da riqueza inventariada entre 1870-1890 na localidade estava sob a forma de imóveis e 33,6\% de ativos financeiros e estoques, cifras que passam $55,2 \%$ e $44,2 \%$, respectivamente, no período 1895-1915. Em relação aos ativos financeiros e estoques, a análise mostra que as ações e quotas de empresas, que representavam $17,4 \%$ dos ativos financeiros no primeiro período, alcançaram a marca de 24,3\% para os anos 1895-1915. Para o autor, dialogando com o trabalho de Mello (1990), o que ocorria era um vazamento de capital de ativos tradicionais - como os escravos - para formas mais capitalistas de acumulação da riqueza, movimento impulsionado pela forte acumulação cafeeira em Campinas que gerava e induzia à diversificação dos capitais.

Todavia, os trabalhos de Lopes $(2016,2007)$ e Abrahão (2016) não apontam de maneira mais evidente qual teria sido o momento em que a riqueza desses inventariados teria de fato se diversificado, posto que os inventários mostram a forma final de acumulação e não a dinâmica que gera esse movimento de realocação da riqueza. O trabalho de Mello (1990, p. 66-102), ao levantar inventários post-mortem na cidade de São Paulo entre 1845-1895, é o que mais se aproxima do espocar da diversificação da riqueza. Se no período 1881-1887, os inventariados paulistanos tinham 53\% de sua riqueza em imóveis e apenas 13\% em valores mobiliários (que incluem as ações de empresas), já no período 1888-1895 esses números são de 33\% para os imóveis e de 31\% para os valores mobiliários: a participações das ações de empresas, que era de $5 \%$ no ano de 1888 , saltou para $24 \%$ no período 1889-1894. Para Mello (1990, p. 89), a busca por ações de empresas resultava da transição de uma economia de base escravista à capitalista, na qual cada vez mais se consolidaria a presença de ativos abstratos, como os papéis de empresas. Entretanto, a autora não atrela diretamente a conjuntura gerada no período do Encilhamento como propulsora dessa diversificação da riqueza. ${ }^{10}$

Ao descrever as facilidades geradas pelas medidas econômicas do início da República em relação à formação de sociedades anônimas e captação de crédito na economia paulista, Saes (1986a, p. 103-110) enfatiza que na década de 1890 os representantes do grande capital cafeeiro ampliaram o movimento de diversificação de seus investimentos. Se antes eles ficavam mais restritos aos papéis de ferrovias e alguns serviços urbanos, em meio à conjuntura do Encilhamento os no-

10 No capítulo II de seu trabalho, ao descrever as formas tradicionais e modernas de riqueza, Mello (1990, p. 89) coloca sucintamente que "O aumento neste período, verificado também em termos de participação na riqueza associa-se ao aparecimento de inúmeras companhias no período denominado Encilhamento". 
vos bancos, empresas comerciais e a indústria passam a ser cada vez mais visados como formas de alocação do capital.

É justamente na compreensão de como o período do Encilhamento contribuiu para a diversificação da riqueza na economia cafeeira paulista que nosso trabalho busca dar uma contribuição. ${ }^{11}$ Para tanto, tomamos como centro da análise a figura de José de Lacerda Guimarães, grande proprietário rural e membro da família Lacerda Franco, que, em 1887, recebeu o título de barão de Arary, em referência à sua importância socioeconômica no município paulista de Araras. ${ }^{12} \mathrm{Na}$ década de 1880, o Barão de Arary era sócio da J. F. de Lacerda $\mathcal{E}$ Cia., casa comissária e exportadora - com sede em Santos (SP) e filiais no Rio de Janeiro e Hâvre (França) - que foi a principal firma exportadora de café em Santos no biênio 1885-1886 (RELATÓRIO..., 1887). Além de sócio, José de Lacerda Guimarães era correntista da casa exportadora em virtude da necessidade de escoar a produção cafeeira de sua fazenda localizada em Araras, a Montevidéo, bem como provê-la com os mais diversos produtos. ${ }^{13}$ Dentre as várias transações de crédito e débito apontadas pela conta-corrente de José de Lacerda Guimarães junto à casa J. F. de Lacerda $\mathcal{E}$ Cia. - base documental do trabalho que cobre o período 1883-1893, quando a casa entrou em liquidação -, notamos que a partir de 1885 tornaram-se presentes as entradas de ações, ou seja, José de Lacerda Guimarães havia adquirido papéis de empresas que faziam chamadas públicas para que seus acionistas integralizassem o capital das ações, pagamentos que a J. F. de Lacerda $\mathcal{E}$ Cia. executava em seu nome, ajustando os débitos com ele posteriormente em sua conta-corrente (CONTAS..., [1893]).

11 Almico (2001, p. 100-119), baseada em inventários post-mortem, relata a diversificação na economia de Juiz de Fora entre 1870-1914, localidade que compunha a Zona da Mata mineira, a mais importante região cafeeira das Minas Gerais na segunda metade do XIX. A autora mostra que no período 1880 -1888 a riqueza concentrava-se em dívida ativa (24\% do total), escravos (16\%), cafezais (16\%) e terras (15\%); mas, no ano de 1892, as três principais formas de alocação da riqueza foram os títulos (42\% do total), as dívidas ativas (23\%) e as ações de empresas (10\%). Para Almico (2001, p. 114), "Não podemos esquecer que esse é o ano da crise do encilhamento, quando a emissão de títulos cresceu assustadoramente, causando a falência de empresas que foram criadas para especulação, as quais levaram consigo outras tantas que não foram criadas para esse fim $[\ldots] "$.

12 Localizada na zona da Estrada de Ferro Paulista, vizinha às cidades de Limeira e Rio Claro, Araras foi elevada à vila em 24 de março de 1871 e se tornou uma cidade em 1879. Seus cafezais formados na metade do século XIX produziram 500.000 arrobas de café no ano de 1886, safra que foi a quarta maior da província de São Paulo naquele ano (MILLIET, 1982, p. 54). Na lista dos votantes de Araras em 1876, José de Lacerda Guimarães e seu irmão Bento de Lacerda eram classificados como fazendeiros e, com uma renda de 20 contos de réis, estavam entre os três indivíduos mais ricos da localidade (LISTA..., 1876).

13 Em 1897, quando morreu o Barão de Arary, seu inventário mostra que a fazenda Montevidéo possuía uma área total de 827,5 alqueires, sendo - 270 alqueires ocupados pelos cafezais, 27,07 alqueires em matas próprias para café, 339 alqueires de terras baixas para mantimentos, 48,08 alqueires de terras ordinárias, 138 alqueires ocupados pelos pastos e fechos e quatro alqueires ocupados pelas benfeitorias. Somados os valores da fazenda, suas benfeitorias, cafezais e animais, totalizaram 1.817 contos de réis, o equivalente a 31\% de sua riqueza bruta (INVENTÁRIO..., [1897]). 
Essas compras de ações de empresas como ferrovias, companhias de navegação, bancos, firmas têxteis e exportadoras de café apresentam importante clivagem: entre 1885-1888, José de Lacerda Guimarães despendeu um valor equivalente a 2.945 libras esterlinas na compra de ações de apenas duas empresas; mas, entre 1889-1893 - não possuímos a conta corrente do ano 1892, o que faz com que os períodos analisados tenham três anos cada um -, esses valores alcançaram 20.003 libras em ações de oito empresas, sendo que seis foram criadas entre 18891891, justamente o período do Encilhamento.

Dessa forma, debruçamos nossa análise nas operações de entrada de ações levadas a cabo pela J. F. de Lacerda $\mathcal{E}$ Cia. em nome de seu sócio e correntista José de Lacerda Guimarães, o Barão de Arary, entre 1885-1893. A pertinência se encontra no vulto de tais negócios alcançados, sobretudo a partir de 1889, tendo em conta a elevação no montante de capitais despendidos e na maior variedade de empresas arroladas. Sendo assim, pensamos que as medidas creditícias e institucionais que caracterizaram o Encilhamento, em que pese a crise cambial e a inflação posteriores - cujas causas vão além da política monetária interna -, geraram um ambiente favorável à formação de empresas no Brasil, como apontam os trabalhos de Stein (1979), Fishlow (1972), Versiani (1980, Suzigan (2000) e Haber (1991), bem como à diversificação dos investimentos dos representantes do grande capital cafeeiro, como indica Saes (1986a). Ademais, possibilitaram aos representantes do grande capital cafeeiro paulista diversificarem ainda mais seus investimentos, movimento que parece ter ganhado maior fôlego no período do Encilhamento, mas que ainda não foi bem contemplado pelos trabalhos sobre a diversificação da riqueza na economia paulista.

\section{José de Lacerda Guimarães e a Formação do Complexo Cafeeiro Paulista (1877-1888)}

A conversão dos canaviais em áreas produtoras de café no interior da província de São Paulo, sobretudo na região que ficaria conhecida como Oeste Paulista, deu-se a partir da metade do século XIX. O avanço do café na terra roxa paulista consolidou-se entre 1876-1883, período em que a capacidade produtiva dos cafeeiros dobrou, ao passo que as ferrovias eram instaladas e as fazendas adotavam as máquinas de beneficiamento, diminuindo o tempo de transporte e agregando valor ao produto (CANO, 1981, p. 31-35; PETRONE, 2010, p. 148-154). ${ }^{14}$

14 Até 1867, ano em que se iniciaram as atividades da São Paulo Railway, todo o transporte do café entre o interior e o litoral era feito no lombo de mulas e por escravos - demandando cerca de um terço dos cativos das fazendas -: por exemplo, os fretes do café saído de Rio Claro a Santos representavam aproximadamente metade de seu preço de exportação. Com as ferrovias, houve uma queda de aproximadamente $20 \%$ nos custos de transporte (CANO, 1981, p. 34; SAES, 2002, p. 182). 
Esse aumento no volume do café produzido demandou a formação de atividades paralelas que viabilizassem a exportação das crescentes safras. Em relação ao transporte, o capital nacional ajudou a constituir a Companhia Paulista de Estradas de Ferro (1868), a Companhia Mogiana de Estradas de Ferro (1872), a Companhia Ituana de Estradas de Ferro (1873) e a Companhia Sorocabana de Estradas de Ferro (1875), que se aliavam à ferrovia São Paulo Railway, em iniciativa do capital inglês (inaugurada em 1867) (SAES, 1986a, p. 40-46). Os bancos, que praticamente inexistiam em São Paulo até a primeira metade do XIX - quadro que pouco evoluiu nos anos 1860 -, com a notícia de dois bancos formados também viram um processo de expansão na década de 1870, quando houve o registro de nove agências bancárias na província: quatro delas em Santos, três na cidade de São Paulo e duas em Campinas (SAES, 1988, p. 35).

O próprio comércio do café demandou uma institucionalidade que regesse as relações entre produtores, comissários e exportadores, para safras que eram cada vez maiores. ${ }^{15}$ Nesse sentido, em dezembro de 1870 formou-se a Associação Comercial de Santos (ACS), uma instituição que congregava 106 indivíduos ligados ao alto comércio cafeeiro santista: comissários, exportadores, capitalistas, banqueiros, corretores e armadores que tinham suas atividades na praça comercial de Santos, podendo ser estrangeiros ou nacionais. Considerando os conflitos existentes entre o capital nacional (casas comissárias) versus o capital estrangeiro (casas exportadoras), a ação da ACS buscava diminuir os riscos do comércio cafeeiro, por exemplo, intimando exportadores que, uma vez tendo vendido o café, não repassavam o dinheiro aos comissários no prazo acordado de 30 dias. Já em relação aos comissários, a ACS tentava, por exemplo, evitar a prática de reutilização dos sacos para acondicionar o café, o que poderia danificar o produto (REGULAMENTO..., 1887; RELATÓRIO..., 1887; SILVA, 2015a, p. 228).

Para o período 1873-1891, o trabalho de Pereira (1980, p. 120) arrolou 23 casas comissárias que atuaram na praça comercial de Santos, sendo na maioria iniciativa de grandes fazendeiros paulistas que, além de produtores, diversificavam na intermediação do café de terceiros e sua venda aos exportadores, tornando-se representantes do grande capital cafeeiro. ${ }^{16} \mathrm{~A}$ única dessas firmas que também constava como casa exportadora era a J. F. de Lacerda $\mathcal{E}$ Cia., que teria iniciado suas atividades em julho de 1877, segundo um contrato que a firma Manoel Alves

15 Na cadeia cafeeira paulista no XIX, a figura do ensacador de café pode ser olvidada, visto que era usual a prática de fornecimento de sacos para acondicionar o produto por parte das próprias casas comissárias, cobrando esse insumo aos seus correntistas. Também não citamos o classificador de café, pois essa função ganhará corpo na praça santista a partir de 1917, com a instituição da Bolsa do Café de Santos - antes, o próprio comissário classificava o café (RELATÓRIO..., 1887).

16 "Eram poucos os fazendeiros que também exerciam as demais atividades, e a maior ocorrência de casos em que ele exercia mais de uma se limitava até o serviço de comissariar os negócios cafeeiros, dado que o capital externo praticamente controlava a exportação de café" (CANO, 1981, p. 70-71). 
Ferreira da Silva $\mathcal{E}$ Cia. celebrou, na cidade de Santos, ${ }^{17}$ comprometendo-se a entregar café à casa comissária no prazo de dois meses, o que se efetivou (PEREIRA, 1980, p. 230-231).

Em junho de 1884, a J. F. de Lacerda E Cia. tornou-se uma casa comissária e exportadora, sendo uma empresa essencialmente familiar organizada na forma de sociedade comanditária com capital de 600 contos de réis e com os seguintes sócios: os primos Joaquim Franco de Lacerda (200 contos de réis) e Antonio de Lacerda Franco (200 contos de réis) como sócios solidários; Joaquim Franco de Camargo Junior (140 contos de réis) - tio dos sócios citados - e João Soares do Amaral (60 contos de réis) - cunhado de Joaquim Franco de Lacerda - como sócios comanditários. A casa era gerenciada por Antonio de Lacerda Franco - que receberia 15 contos anuais para essa função - e tinha sede na cidade de Santos e uma filial na capital do Império, sendo sua finalidade o comércio de comissão em geral, compra e venda de café nas praças de Santos e Rio de Janeiro e exportação para o exterior por conta própria ou de terceiros (CONTRATOS..., [1884]). ${ }^{18}$

Para a função exportadora da casa, os Lacerda Franco montaram uma subsidiária na cidade portuária francesa do Havre, que era um importante destino do café santista. ${ }^{19}$ A Lacerda $\mathcal{E}$ Cia. era uma firma com capital social de 1 milhão de francos constituída pelos seguintes sócios: Joaquim Franco de Lacerda (300 mil francos) e Antonio de Lacerda Franco (300 mil francos) como sócios solidários; e José de Lacerda Guimarães (400 mil francos) como sócio comanditário, ele que era pai do primeiro e tio do segundo.

A casa comissária e exportadora dos Lacerda Franco teria importante papel em uma conjuntura extremamente favorável ao negócio cafeeiro. A partir de 1886, iniciava-se um novo ciclo de alta nos preços internacionais do café, que se mantiveram elevados até 1896 nos grandes mercados importadores, como Estados Unidos e França. ${ }^{20}$ No porto de Santos, em que pese o predomínio das casas estrangeiras na exportação do café - firmas estadunidenses, inglesas, francesas e alemãs -, a J. F. de Lacerda $\mathcal{E}$ Cia., única casa nacional entre os 12 maiores expor-

17 A casa se situava na Rua do Santo Antonio, $n^{\circ}$ 50, na cidade de Santos (SILVA, 2011, p. 180). Segundo Moraes (1988, p. 65), na década de 1870, a Vergueiro $\mathcal{Z}$ Cia. e a J. F. de Lacerda $\mathcal{E}$ Cia. eram as principais casas comissárias de Santos.

18 Na capital do Império, a J. F. de Lacerda $\mathcal{E}$ Cia. situava-se na Rua da Alfândega, no 15 (LAEMMERT, 1889, p. 767). Segundo Moraes (1988, p. 45), “[...] era necessário, por motivo de técnica financeira, ter uma representação própria na capital do país em vista da crescente influência da política sobre o comércio. Além disso [...] era preciso fechar as cambiais para importação e exportação naquela cidade.".

19 Entre 1880-1886, os principais destinos do café exportado pelo porto de Santos foram: Havre (França), com 2.718.304 sacas, Estados Unidos, com 2.160.159 sacas, e Hamburgo (Alemanha), com 2.132.774 sacas de café (RELATÓRIO..., 1887).

20 A década de 1880 foi o único decênio, entre 1856 e 1900, em que a demanda mundial por café superou a oferta (SAMPER; FERNANDO, 2003, p. 417-419). O preço do café de Santos no porto francês de Havre, que no ano de 1885 era de 43 francos por saca de 50 quilos, passou para 69 francos em 1886 e chegou a 119 francos em 1889 (BACHA; GREENHILL, 1992, p. 334). 
tadores santistas, foi a empresa que exportou a maior quantidade do café paulista no biênio 1885-1886, com a marca de 489.309 sacas que corresponderam a 13,2\% do total de café exportado através de Santos (RELATÓRIO..., 1887).

Na metade da década de 1880, os Lacerda Franco comandavam a exportação cafeeira santista, condição que foi ratificada com a eleição de Antonio de Lacerda Franco para a presidência da Associação Comercial de Santos no período 1887-1888 (PEREIRA, 1980, p. 60-69). Esse controle vinha das estreitas ligações com importantes cafeicultores paulistas, como José de Lacerda Guimarães, que, ao abrir uma conta-corrente na casa, possibilitava à empresa a obtenção do café a ser exportado (SILVA, 2015b, p. 559-563). Nesse sistema de contas-correntes, a casa também funcionava como um banco para o fazendeiro, que tanto lhe adiantava crédito para as safras quanto fazia pagamentos a terceiros em nome do correntista (FRANCO, 1997, p. 165; STEIN, 1990, p. 113-115; PEROSA, 1980, p. 64). ${ }^{21}$

Quadro 1 - Saldos da conta-corrente de José de Lacerda Guimarães (Barão de Arary) na casa comissária e exportadora J. F. de Lacerda E Cia. (18841891): valores em contos de réis correntes e libras esterlinas constantes

\begin{tabular}{|c|c|c|}
\hline Anos & Saldo (contos de réis correntes) & Saldo (libras esterlinas constantes) \\
\hline 1884 & 44 & 3.884 \\
\hline 1885 & 20 & 1.678 \\
\hline 1886 & 87 & 7.826 \\
\hline 1887 & 84 & 9.195 \\
\hline 1888 & 29 & 3.476 \\
\hline 1890 & 141 & 14.874 \\
\hline 1891 & 48 & 3.253 \\
\hline
\end{tabular}

Fonte: Contas-correntes JLG (CONTAS..., [1893]).

Nota: Para a obtenção dos valores em libras esterlinas constantes, foi utilizado o índice de preços para o Reino Unido de Mitchell (2007, p. 955).

O Quadro 1 aponta que os saldos de José de Lacerda Guimarães na casa J. F. de Lacerda $\mathcal{E}$ Cia., baseando-se nos valores em libras constantes, tornaram-se pronunciadamente maiores a partir de 1886, em congruência com a favorável

21 A relação entre as casas comissárias e os produtores era regulada pelo sistema de contas-correntes: o fazendeiro abria uma conta-corrente na casa, que, no lado dos débitos (deve), constavam todos os compromissos financeiros saldados pela casa em seu nome: empréstimos junto a bancos, entrega de sacos para acondicionar o café, alimentos e materiais para a fazenda, compra de ações de empresas, remessas de dinheiro para ele ou terceiros. Já no lado do crédito (haver), constavam os valores a receber: os pagamentos da casa pelo café remetido, os dividendos das ações de empresas e a quitação de empréstimos anteriormente concedidos. Ao final do ano cafeeiro, que se dava em 30 de junho, era apurado o saldo da conta-corrente, que, caso demonstrasse resultado positivo, podia ser sacado ou mantido na casa rendendo juros de $6 \%$ ao ano; mas, se o resultado fosse negativo, a casa cobrava do fazendeiro juros de $12 \%$ ao ano sobre o valor devido (CONTAS..., [1893]). 
conjuntura do café no mercado internacional e junto à relevante posição que a casa comissária e exportadora adquirira em Santos. No caso do Barão de Arary, a questão que se colocava era se ele manteria os saldos na casa, recebendo juros de $6 \%$ - sendo que ele pagava o dobro pelo capital adiantado pela casa - ou se investiria esse capital acumulado ao final de cada ano cafeeiro.

A inversão em novos cafezais há de ter sido uma realidade para diversos proprietários agrícolas paulistas, posto que em 1880 havia 106 milhões de cafeeiros em produção, número que chegou a 211 milhões no ano de 1888 (CANO, 1981, p. 41). Todavia, opções de alocação dos capitais se colocavam aos representantes do grande capital cafeeiro, a corroborar, como expõe Saes (1986a, p. 103), a "vocação" desses indivíduos para adentrar em outros setores da economia paulista que, na década de 1880, tendiam a ser o setor ferroviário e os serviços públicos.

Quadro 2 - Valores gastos com a entrada de ações de empresas por parte de José de Lacerda Guimarães (Barão de Arary) através da casa comissária e exportadora J. F. de Lacerda E Cia. (1885-1888): valores em milhares de réis (Rs.)

\begin{tabular}{|l|c|c|c|}
\hline \multicolumn{1}{|c|}{ Empresas } & $\mathbf{1 8 8 5 - 1 8 8 6}$ & $\mathbf{1 8 8 6 - 1 8 8 7}$ & $\mathbf{1 8 8 7 - 1 8 8 8}$ \\
\hline $\begin{array}{l}\text { Companhia Paulista de Vias Férreas e Fluviais } \\
\text { (1883) }\end{array}$ & 10.312 & 5.407 & 5.407 \\
\hline Companhia Ferroviária Rio Claro-Jaú (1884) & & 7.048 & \\
\hline \multicolumn{1}{|c|}{ Total } & 10.312 & 12.455 & 5.407 \\
\hline
\end{tabular}

Fonte: Contas-correntes JLG (CONTAS..., [1893]).

Nota: Entre parênteses encontra-se o ano de criação da empresa.

Segundo o Quadro 2, a conta-corrente de José de Lacerda Guimarães junto à J. F. de Lacerda $\mathcal{E}$ Cia. demonstra que ele teve entre seus débitos pagamentos que a casa fez em seu nome referentes às entradas de ações de duas empresas: a Companhia Paulista de Estradas de Ferro e Vias Fluviais (Navegação do Rio Mogi-Guaçu) e a Companhia de Estradas de Ferro Rio Claro. O Barão de Arary resolveu diversificar sua riqueza através da compra de ações da Companhia Paulista de Vias Férreas e Fluviais, empresa que foi criada em 1883, e em dezembro de 1884 abriu a navegação de seus vapores pelo rio Mogi-Guaçu, na região que cobria do município paulista de Porto Ferreira a Ribeirão Preto, no que seria a maior zona produtora de café do mundo (DOMINGUES NETO, 2009, p. 56-57).22

Em relação à Companhia Ferroviária Rio Claro, formada em 1884 e que seria posteriormente comprada pela Paulista em 1892, se apresentava como promissor investimento cujos trilhos chegavam até Jaú, localidade que seria a fronteira

22 Os nomes dos vapores da Companhia Paulista indicavam a importância do grande capital cafeeiro na formação desse empreendimento. Os nomes das embarcações eram: Conde d'Eu, Nicolau Queiroz, Elias Chaves, Antonio Prado, Barão de Jaguara, Fidêncio Prates, Antonio Paes, Eduardo Prates, Elias Fausto, José de Queiroz e Antonio de Lacerda Franco (DOMINGUES NETO, 2009, p. 98). 
agrícola nas décadas de 1890 e 1900, servindo para atrair importantes figuras do grande capital cafeeiro, como os Almeida Prado, Antônio Carlos de Arruda Botelho (Conde do Pinhal) e o presidente Campos Salles, todos visando a ascendente produção cafeeira nessas novas terras (FALEIROS, 2010, p. 329-330).

O móvel que os induzia na busca desse tipo de investimento era a garantia de juros que o governo concedida às ferrovias e os dividendos pagos aos acionistas, fatores que explicavam a elevada demanda por ações de firmas ferroviárias. Além disso, elas eram as responsáveis pelo transporte do café do interior à zona portuária, atividade que se viu dinamizada nesse período de expansão dos cafezais pelo Oeste Paulista rumo à região de Ribeirão Preto, fazendo os lucros de tais firmas crescerem e, por consequência, os dividendos aos acionistas (HANLEY, 2005, p. 74-75).

Apesar do capital despendido pelo Barão de Arary na compra de ações de empresas, percebemos que a diversificação de seus capitais se dava de forma ainda restrita, posto não haver entrada de ações além das existentes em companhias ferroviárias, investimento cujo risco parecia ser menor em uma conjuntura marcada pelos debates acerca do fim da escravidão. Em uma economia escravista, a imobilização do capital na compra e manutenção dos escravos, somas que muitas vezes vinham de terceiros e sob a cobrança de juros, implicava em elevados custos fixos aos fazendeiros e amarrava à propriedade boa parte dos capitais. Em contraste, no regime de trabalho livre havia maior fluidez dos investimentos, pois os custos fixos se tornam circulantes e divididos com o colono, cujo salário e a própria oferta de trabalho podia se ajustar às conjunturas econômicas adversas (COSTA, 2007, p. 341; SAES, 1992, p. 5-7; CANO, 1981, p. 40; DELFIM NETTO, 2009, p. 46-47).

Após a abolição, e em uma conjuntura de forte acumulação devido às elevadas cotações do café no mercado internacional, veremos que houve uma aceleração na metamorfose da riqueza paulista expressa pela menor incidência das formas tradicionais de acumulação - escravos e dívidas ativas - para modalidades mais modernas e capitalistas de alocação da riqueza, como os valores mobiliários - ações de empresas, contas e letras bancárias -, movimento que foi impulsionado pelas medidas econômicas que resultariam no Encilhamento (MELLO, 1990, p. 250).

\section{Barão de Arary e a Diversificação de seus Investimentos no Complexo Econômico Paulista (1889-1897)}

Com a consolidação da mão de obra assalariada pós-1888, formou-se um mercado de trabalho e um mercado consumidor, ambos baseados no trabalhador livre. Os vencimentos que esses assalariados recebiam pela venda dos produtos agrícolas e outros fabricos alimentavam a produção de uma indústria nascente 
que se concentrava no setor de bens de consumo não duráveis, como os têxteis e alimentícios (CARDOSO, 1960, p. 35-38). ${ }^{23}$

A crescente demanda por numerário em uma economia em plena transição capitalista balizou as medidas econômicas do governo republicano após novembro de 1889. Rui Barbosa, o novo ministro da Fazenda, empreendeu reformas em janeiro de 1890 que ampliaram o mercado creditício e facilitaram a formação de sociedades anônimas ao estabelecer a responsabilidade limitada para os acionistas das empresas e, concomitantemente, criar bancos de emissão, que, além dessa prerrogativa monetária, possuíam a faculdade de investir em empresas (MARCONDES; HANLEY, 2010, p. 111-112).

O estado de São Paulo também presenciou os efeitos da "febril atividade econômica como jamais se conhecera no país” (FURTADO, 2000, p. 176). Na cidade de São Paulo, foram constituídas ao menos 222 sociedades por ações (bancos e demais empresas) nos seis meses posteriores às medidas de 17 de janeiro de 1890 , sendo que em 1887 havia apenas 30 sociedades por ações paulistas. Tamanho volume na negociação dos papéis dessas novas empresas ensejou inclusive a formação da Bolsa de Valores de São Paulo, em agosto de 1890 (HANLEY, 2005, p. 87).

Quadro 3 - Valores gastos com a entrada de ações de empresas por parte de José de Lacerda Guimarães (Barão de Arary) através da casa comissária e exportadora J. F. de Lacerda E Cia. (1885-1888): valores em milhares de réis (Rs.)

\begin{tabular}{|c|c|c|c|}
\hline Empresas & $1889-1890$ & 1890-1891 & $1892-1893$ \\
\hline Cia. Paulista de Estradas de Ferro (1868) & 27.287 & 43 & \\
\hline $\begin{array}{l}\text { Cia. de Estradas de Ferro do Muzambinho } \\
\text { (1889) }\end{array}$ & 8.000 & 7.960 & 5.320 \\
\hline $\begin{array}{l}\text { Banco do Comércio e Indústria de São Paulo } \\
\text { (1889) }\end{array}$ & 40.000 & & \\
\hline Banco União de São Paulo (1890) & 50.000 & 51.000 & \\
\hline $\begin{array}{l}\text { Companhia Lacerda (exportação de café) } \\
\text { (1891) }\end{array}$ & & 2.500 & \\
\hline Companhia Têxtil Fabril Paulistana (1886) & & 7.200 & \\
\hline Banco Ítalo-Brasileiro (1890) & & 20.000 & \\
\hline Banco de Santos (1890) & & 5.520 & 1.520 \\
\hline TOTAL & 125.287 & 94.223 & 6.840 \\
\hline
\end{tabular}

Fonte: Contas-correntes JLG (CONTAS..., [1893]).

Nota: Entre parênteses encontra-se o ano de criação da empresa.

23 Pontuamos que a indústria nascente em São Paulo, concentrada no setor alimentício e têxtil, tinha sua demanda lastreada pelo consumo das camadas médias e baixas. De outra parte, o consumo dos membros da elite do grande capital cafeeiro, dada sua busca pela diferenciação social, traduzia-se em uma preferência por mercadorias importadas, como demonstra Oliveira (2014, p. 180-184). 
Pelo Quadro 3, evidenciamos que o Barão de Arary ampliou a diversificação de seus investimentos. Antes, segundo o Quadro 2, os pagamentos que a casa J. F. de Lacerda $\mathcal{E}$ Cia. realizou em seu nome referente às entradas de ações de empresas resumiam-se às duas companhias ferroviárias. Todavia, no período 1889-1893, foram listadas oito companhias em que o Barão efetuou dispêndios referentes às entradas de ações, sendo que apenas duas dessas empresas haviam sido criadas antes de 1889 - a Cia. Paulista de Estradas de Ferro (1868) e a Companhia Têxtil Paulistana (1886).

Segundo Saes (1986a, p. 102), esse movimento de inserção em outros setores econômicos caracterizou os representantes do grande capital cafeeiro paulista na década de 1890. Nesse sentido, os investimentos de José de Lacerda Guimarães corroboram a tese de Saes, uma vez que mantinham-se os papéis de ferrovias (Cia. Paulista de Estradas de Ferro e Cia. de Estradas de Ferro do Muzambinho), mas havia também quatro bancos (Banco do Comércio e Indústria de São Paulo, Banco União de São Paulo, Banco Ítalo-Brasileiro e Banco de Santos), uma firma têxtil (Companhia Têxtil Fabril Paulistana) e uma casa comissária e exportadora de café (Companhia Lacerda).

Os investimentos em papéis de bancos predominavam nas entradas de ações do Barão, representando $74 \%$ dos pagamentos totais que a casa J. F. de Lacerda $\mathcal{E}$ Cia. efetuou referentes a esse tipo de operação. ${ }^{24} \mathrm{O}$ Banco União de São Paulo, que isoladamente respondeu por $45 \%$ dos gastos totais do Barão de Arary, foi um dos bancos emissores instituídos pelo governo republicano, tendo sido criado em 31 de janeiro de 1890 por Antonio de Lacerda Franco (presidente do banco) ${ }^{25}$ e João Baptista de Mello $^{26}$, membros do grande capital cafeeiro, assim como os demais membros da primeira diretoria do banco. ${ }^{27}$ Sua natureza de banco universal lhe permita realizar atividades de crédito comercial, agrícola e hipotecária, industrial, sendo que em 1891 - quando seu ativo de 112 mil contos de réis fazia dele

24 A predominância dos bancos na alocação dos dispêndios do Barão de Arary se coaduna aos dados apresentados por Lobo (1976, p. 271) em relação à Bolsa de Valores do Rio de Janeiro, que, entre 1890-1893, viu os bancos responderem por $57 \%$ dos valores totais negociados através de seus títulos, seguidos das empresas de transporte, principalmente as ferrovias, com $26 \%$ dos títulos negociados.

25 Antonio de Lacerda Franco, filho de Bento de Lacerda Guimarães (Barão de Araras), foi gerente da casa comissária e exportadora J. F. de Lacerda $E$ Cia. e senador estadual em 1892, chegando ao senado federal no período entre 1924 e 1930; foi também membro da comissão executiva do PRP entre 1901-1906 e 1914-1927 (SILVA, 2011).

26 João Baptista de Mello Oliveira era importante cafeicultor na região de Rio Claro (SP) e foi um dos fundadores do PRP e senador estadual entre 1892-1903 (SILVA, 2011, p. 232).

27 Joaquim Lopes Chaves (senador estadual em 1894 e 1901 e cunhado de Américo Brasiliense, que foi o primeiro presidente do Estado de São Paulo), Antonio Paes de Barros (senador estadual em 1903, filho do Barão de Piracicaba e sobrinho do brigadeiro Rafael Tobias de Aguiar), Bento Quirino dos Santos (vereador de São Paulo e presidente da Companhia Mogiana de Estradas de Ferro), João Tobias de Aguiar e Castro (senador estadual em 1892, filho da Marquesa de Santos e do brigadeiro Rafael Tobias de Aguiar) e Vitoriano Gonçalves Camilo (SILVA, 2011, p. 232). 
o maior banco paulista em 1892 - ele montou a Fábrica de Chitas Votorantim, na cidade de Sorocaba (SP), que se tornaria a maior empresa do setor têxtil paulista na década de 1930 (SILVA, 2011, p. 214-220; MARCONDES; HANLEY, 2010, p. 112-113; HANLEY, 2005, p. 155).

Por sua vez, o Banco do Comércio e Indústria de São Paulo, que absorveu 18\% dos valores de entradas de ações, originou-se em 1885, como a Casa Bancária da Província de São Paulo (Nielsen E Cia). Seus sócios eram Carlos P. Nielsen e Antonio Luiz Tavares, à época gerentes do London and Brazilian Bank em São Paulo e em Santos. Entre os diretores e acionistas, desde sua fundação, havia elementos com negócios ligados a outros ramos do grande capital cafeeiro: proprietários de fazendas de café, acionistas de estradas de ferro, homens ligados ao comércio exportador, entre outros. Em dezembro de 1889, a Casa Bancária da Província de São Paulo (Nielsen $\mathcal{E}$ Cia.) se transformou no Banco do Comércio e Indústria de São Paulo, que era o terceiro maior banco paulista em 1892, com um ativo de 34 mil contos de réis - e se tornaria o maior banco comercial do estado na década de 1920 (SAES, 1986b, p. 88; CHAVANTES, 2004, p. 68).

Ainda em relação aos bancos, houve investimentos do Barão de Arary no Banco de Santos - o oitavo maior banco paulista em 1892, com um ativo de 12 mil contos - e no Banco Ítalo-Brasileiro - $13^{\circ}$ banco paulista, com um ativo de sete mil contos -, sendo o primeiro um banco universal criado em 1890 e o segundo uma casa bancária fundada em 1891 para atender à demanda de capital dos italianos no Brasil e a remessa de suas rendas à Europa, que tinha como um de seus diretores o industrial Alexandre Siciliano (MARCONDES; HANLEY, 2010, p. 105).

Quanto às ferrovias, que somaram 21\% dos valores referentes às entradas de ações, vemos que a compra de ações da Companhia Paulista de Estradas de Ferro continuava sendo um investimento visado pelo Barão de Arary, que adquiriu ações em nome próprio e também no de sua esposa Maria Dalmacia de Lacerda (Baronesa de Arary) e de sua filha Maria Ottilia, constando o Barão como o quarto principal acionista da ferrovia em 1892, entre 890 indivíduos, detendo 3.426 ações da Paulista, o que representava 2,28\% das 150.000 ações que se encontravam distribuídas entre os 890 acionistas da empresa ferroviária (SAES, 1981, p. 45, 93 e 192). ${ }^{28}$

Também no afã de diversificar os investimentos, o Barão de Arary, assim como outros abastados, ${ }^{29}$ adquiriu ações da Estrada de Ferro do Muzambinho

28 Os principais acionistas da Paulista em 1892 eram: Eduardo Prates (5.259 ações), Veridiana Prado (5.070 ações), seu filho Martinho Prado Junior (3.578 ações), o Barão de Arary (3.426 ações) e o Barão de Souza Queiroz (3.286 ações) (SAES, 1981, p. 192).

29 A atratividade da Estrada de Ferro do Muzambinho vinha não só do tráfego de cargas e passageiros, mas também da garantia de juros de $4 \%$ durante sua construção e $5 \%$ depois de aberto o tráfego, garantia de juros que chegariam a 6\% em 1893 (BATISTA; BARBOSA; GODOY, 2012, p. 174). 
entre 1889-1893, visto que, na década de 1890, as Minas Gerais se tornaram o segundo maior produtor cafeeiro do Brasil e o sul mineiro era importante zona abastecedora de alimentos para São Paulo e Rio de Janeiro. Essa empresa veio da concessão de uma ferrovia que deveria partir de Muzambinho e viria até São Joaquim da Serra Negra (município de Alfenas), concessão originalmente da ferrovia Minas e Rio, que abdicou desse trecho. A Muzambinho foi inaugurada em 1892, partindo de Três Corações e passando por Varginha. Em 1899, a estrada foi encampada pelo governo de Minas e, em 1908, foi incorporada à Estrada de Ferro Minas e Rio (CANO, 2002, p. 52; BATISTA; BARBOSA; GODOY, 2012, p. 186; PIMENTA; ELEUTÉRIO; CARAMURU, [s.d.], p. 6; MELLO, 1990, p. 200).

A diversificação dos investimentos se dava também através da participação em sociedades fabris. José de Lacerda Guimarães, entre 1890-1891, adquiriu ações da Companhia Fabril Paulistana, tecelagem criada em 1884 no bairro paulistano do Bom Retiro e que produzia tecidos com algodão que vinham do Nordeste (VERONA, 1999, p. 21). Através da ata da assembleia geral de 24 de setembro de 1895, vemos que essa firma tinha entre seus acionistas proeminentes figuras do grande capital cafeeiro, como Antonio Proost Rodovalho e Eduardo Prates, além do Barão de Arary. ${ }^{30}$ Esses investimentos eram característicos dos representantes do grande capital cafeeiro, que optavam muitas vezes por alocar seus capitais em empresas que eles dirigiam, de forma direta ou através de participação acionária (MELLO, 1990, p. 203-206).

Além dessas empresas, o Barão de Arary adquiriu ações da Companhia Lacerda, que, na realidade, tratava-se de uma reestruturação da casa comissária e exportadora J. F. de Lacerda $\mathcal{E}$ Cia. No dia $1^{\circ}$ de julho de 1891, na sede do Banco União de São Paulo, foi constituída a Companhia Lacerda, cuja finalidade eram os negócios de comissão e exportação de café e demais gêneros agrícolas, a partir de sua sede em Santos (SP) e a filial francesa da cidade do Havre. Essa sociedade surgia da liquidação dos negócios da J. F. de Lacerda $\mathcal{E}$ Cia., sendo agora uma sociedade por ações com um capital de 10 mil contos de réis - dividido em 100 mil ações de 100 mil-réis cada uma. O presidente da Companhia Lacerda era Antonio de Lacerda Franco - que havia sido gerente da antiga casa exportadora e era presidente do Banco União de São Paulo - e na diretoria havia diversos membros do grande capital cafeeiro paulista: João Baptista de Mello Oliveira (vice-presidente do Banco União), Eduardo Prado, Elias Fausto Pacheco Jordão, Elias Augusto do Amaral Souza, Ignácio Penteado (SÃO PAULO, 1891, p. 391-393).

30 (DIÁRIO..., 1890, 1895a, 1895b). 
Gráfico 1 - Valores gastos com a entrada de ações de empresas por parte de José de Lacerda Guimarães (Barão de Arary) através da casa comissária e exportadora J. F. de Lacerda E Cia. (1885-1893): valores em libras esterlinas constantes

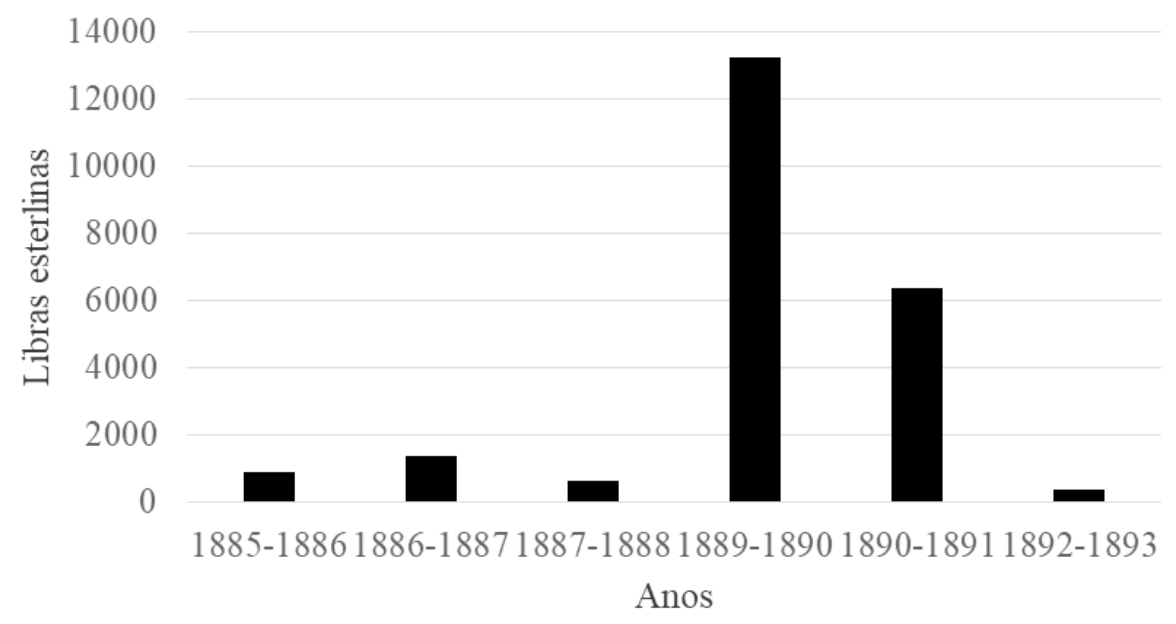

Fonte: Contas-correntes JLG (CONTAS..., [1893]).

Nota: Para a obtenção dos valores em libras esterlinas constantes foi utilizado índice de preços para o Reino Unido de Mitchell (2007, p. 955).

Além da diversidade de empresas que o Barão de Arary passou a adquirir papéis após 1888, o Gráfico 1 demonstra que houve um crescimento real em seus valores movimentados, que tiveram uma média de 982 libras esterlinas entre os anos 1885-1888 e, entre 1889-1893, passaram a 6.688 libras. Ademais, se excluirmos o ano de 1893, em que a casa J. F. de Lacerda $\mathcal{E}$ Cia. estava em liquidação, quando a conta-corrente do Barão de Arary apresentou pela primeira vez um déficit - que chegou a 530 contos de réis a favo da casa -, teremos uma média de 9.808 libras para o período 1889-1891, justamente na conjuntura aguda do Encilhamento (CONTAS..., [1893]).

Os dados trazidos anteriormente (ver Quadros 2 e 3 e Gráfico 1) corroboram as colocações de Saes (1986a), Mello (1990) e Hanley (2005) acerca da importância das medidas econômicas do Encilhamento (1889-1893) para acelerarem o movimento de diversificação dos investimentos por parte de um dos representantes do grande capital cafeeiro paulista na década de 1890. A partir de 1889, o Barão de Arary teve elevados dispêndios com as operações de entradas de ações e investiu em um número maior de empresas, em relação ao período 1885-1888.

A difusão dos investimentos de José de Lacerda Guimarães a partir de 1889 alia-se à tese de Cano (1981), Silva (1995), Mello (2009) e Aureliano (1999) sobre o vazamento de capitais aos outros elos do complexo cafeeiro, quando do auge exportador do final da década 1880 e início dos 1890, pois constaram entradas 
de ações das tradicionais ferrovias, mas também de bancos, casa comissária e exportadora de café e uma empresa têxtil. Este último investimento em uma firma industrial - a Cia. Fabril Paulistana ${ }^{31}$ - coaduna-se à visão de Stein (1979), Fishlow (1972), Versiani (1980 e Suzigan (2000), que denotam a importância do período do Encilhamento para a expansão da indústria no Brasil, a partir das mudanças institucionais que geraram um cenário de avanço creditício e mais facilidades à formação de empresas, como aponta Haber (1991), conjuntura que teria favorecido a indústria nascente, tendo como exemplo o setor têxtil.

Quadro 4 - Ações de empresas que constam entre os ativos no inventário do Barão de Arary (1897): valores em milhares de réis

\begin{tabular}{|l|c|c|}
\hline \multicolumn{1}{|c|}{ Empresas } & Ações & Valor total (Rs.) \\
\hline Banco do Comércio e Indústria de São Paulo & 870 & 261.000 \\
\hline Banco União de São Paulo & 508 & 12.344 \\
\hline Banco de Santos & 76 & 1.900 \\
\hline Companhia Paulista de Vias Férreas e Fluviais & 6.869 & 1.899 .279 \\
\hline Companhia Estrada de Ferro do Muzambinho & 26 & 133 \\
\hline Companhia Carris de Ferro de São Paulo a Santo Amaro & 3 & 210 \\
\hline Companhia Mecânica e Importadora de São Paulo & 1.500 & 180.000 \\
\hline Companhia Fabril Paulistana & 400 & 72.000 \\
\hline Companhia Lacerda & 155 & 1.200 \\
\hline Companhia Paraná Industrial & 500 & 2.500 \\
\hline
\end{tabular}

Fonte: Inventário Barão de Arary (INVENTÁRIO, [1897]).

Quando da morte do Barão de Arary, em 13 de outubro de 1897 no distrito mineiro de Caxambú, sua riqueza alcançou o valor de Rs. 5.876:617\$912, posicionando-o como um dos mais ricos inventariados paulistas no final do século. ${ }^{32}$ Desse valor, $41 \%$ eram referentes às ações de empresas, sendo que, ao excluir os valores das ações da Companhia Mecânica e Importadora de São Paulo e da Companhia Paraná Industrial, constatamos que as empresas restantes são aquelas

31 A Fábrica de Tecidos Anhaia, pertencente à Cia. Fabril Paulistana e situada na cidade de São Paulo, era a décima maior empresa têxtil algodoeira paulista em 1910 - havia 24 empresas no ramo têxtil algodoeiro naquele ano - com capital de 2 mil contos de réis, 500 operários, 300 teares e 8.254 fusos (BOLETIM..., 1912, p. 308-309).

32 Ao compararmos a riqueza bruta do Barão de Arary com os dez inventários com maiores valores de Monte-Mor, arrolados por Mello (1990), de indivíduos que morreram e com os processos que estavam no $1^{\circ}$ Ofício da Família na cidade de São Paulo, vemos que ele tinha uma riqueza menor apenas que a de Joaquim Egídio de Souza Aranha (Barão de Três Rios). Este foi um dos precursores do café em Campinas, onde foi vereador e presidente da Câmara, além de deputado provincial e vice-presidente da província em 1878. Foi, além de grande acionista, diretor da Companhia Paulista de Estradas de Ferro e da Mogiana, vice-presidente do Banco do Comércio e Indústria. Ao morrer, em 1893, ele deixou uma riqueza bruta de Rs. 18.557:740\$772 (MELLO, 1990, p. 134-164). 
que constam nas entradas de ações que a casa J. F. de Lacerda $\mathcal{E}$ Cia. efetuou em nome do Barão de Arary, principalmente entre 1889-1891, somando esses papéis $38 \%$ da riqueza bruta de José de Lacerda Guimarães.

Dessa forma, tomando como base a diversificação da riqueza de um dos mais importantes representantes do grande capital cafeeiro paulista, asseveramos que as medidas econômicas que caracterizaram o Encilhamento (1889-1893) mostraram-se de fundamental importância para apontar esses anos como o período em que a riqueza do Barão de Arary se dinamizou de maneira mais célere, alcançando os demais elos do complexo cafeeiro paulista, em um movimento que não tinha tal vulto quando esse complexo se calcava em bases escravistas.

\section{Considerações Finais}

A perenidade do debate acerca dos efeitos das medidas econômicas que caracterizaram o final do Império e o começo da República, denominadas de Encilhamento (1889-1893), nos levou a considerar se esse período não teria sido importante aos representantes do grande capital cafeeiro paulista em seu movimento de acumulação e, sobretudo, diversificação da riqueza.

Dada a existência de uma historiografia que se debruçou sobre a alocação da riqueza paulista, mas que não a atrelou diretamente à conjuntura do Encilhamento, entendemos que a análise de José de Lacerda Guimarães (Barão de Arary), um dos mais importantes indivíduos a representar o grande capital cafeeiro na segunda metade do XIX, poderia contribuir para clarificar as relações entre o Encilhamento e a diversificação do capital em São Paulo.

Ao analisar a conta-corrente do Barão de Arary na casa comissária e exportadora J. F. de Lacerda $\mathcal{E}$ Cia. entre 1883-1895, deparamo-nos com as operações de entradas de ações, que se tratavam de pagamentos que a casa fazia em nome do Barão - debitando os valores em sua conta - referentes à compra de ações de empresas. No período 1885-1888, essas operações concentravam-se na compra de papéis de companhias ferroviárias, um tradicional e seguro investimento na economia paulista. Mas, no período 1889-1893, além de manutenção das ferrovias, ocorreu a compra de ações de bancos, empresa têxtil e casa comissária e exportadora de café, sendo que os valores movimentados foram pronunciadamente mais elevados no segundo período.

Assim, o artigo demonstra que o Encilhamento, em que pese efeitos adversos no quadro macroeconômico do início da República, foi elemento-chave para a diversificação do capital dos maiores proprietários paulistas, que se tornavam cada vez mais representantes do grande capital cafeeiro, ao aprofundarem sua participação nesse complexo econômico. 


\section{Referências}

\section{Fontes primárias}

REGULAMENTO interno da Associação Comercial de Santos. Santos: Typographia a valor do Diário de Santos, 1887.

RELATÓRIO da Associação Comercial de Santos apresentado na Assembleia Geral de março de 1887. Santos: União Typographica, 1887.

BOLETIM da Diretoria de Indústria e Comércio para o ano de 1922. São Paulo: jul. 1912.

CONTAS correntes de José de Lacerda Guimarães (Barão de Arary) na casa comissária e exportadora J. F. de Lacerda E Cia. Santos, 1883-1893. [S.1., 1893].

DIÁRIO OFICIAL DA REPÚBLICA FEDERATIVA DO BRASIL. Rio de Janeiro: [s.n.], 12 jun. 1890.

DIÁRIO OFICIAL DA REPÚBLICA FEDERATIVA DO BRASIL. Rio de Janeiro: [s.n.], 04 jan. 1895a.

DIÁRIO OFICIAL DA REPÚBLICA FEDERATIVA DO BRASIL. Rio de Janeiro: [s.n.], 15 out. 1895b.

INVENTÁRIO de José de Lacerda Guimarães (Barão de Arary). Processo 226/1897, Pacote 1447/1897. [1897]

CONTRATOS sociais da casa comissária J. F. de Lacerda $\mathcal{E}$ Cia. registrados na Junta Commercial do Rio de Janeiro entre 1881 e 1884. Rio de Janeiro: Arquivo Nacional, [1884].

SÃO PAULO. Ata de constituição da Companhia Lacerda. Diário Oficial do Estado de São Paulo, [São Paulo], 05 jul. 1891.

LISTA dos votantes do município de Araras (SP). Câmara Municipal de Araras (SP), 1876.

\section{Demais fontes bibliográficas}

ALMICO, R. C. S. Fortunas em movimento: um estudo sobre as transformações na riqueza pessoal em Juiz de Fora/1870-1914. 2001, Dissertação (mestrado) - Instituto de Economia, Universidade Estadual de Campinas, São Paulo, 2001.

ALMEIDA, I. C. S.; CROCE, M. A. Abolição, encilhamento e mercado financeiro: uma análise da primeira crise financeira republicana. Revista de Economia do Centro-Oeste, v. 2, n. 2, p. 19-36, 2016.

AURELIANO, L. No limiar da industrialização. Instituto de Economia- Universidade Estadual de Campinas, São Paulo, 1999.

ABRAHÃO, F. A. A. Composição da riqueza em Campinas, 1870-1940. História Econômica 8 História de Empresas, v. 19, 2016.

BACHA, E. L.; GREENHILL, R. 150 anos de café. Rio de Janeiro: Salamandra, 1992. 
BATISTA, F. A.; BARBOSA, L. S; GODOY, M. M. Transportes, modernização e formação regional: subsídios a história da era ferroviária em Minas Gerais, 1870-1940. Revista de História Regional, v. 17, p. 162-203, 2012.

CANO, W. Raízes da concentração industrial em São Paulo. São Paulo: T. A. Queiroz, 1981.

CANO, W. Ensaios sobre a formação econômica regional do Brasil. Campinas: Unicamp, 2002.

CARDOSO, F. H. Condições sociais da industrialização de São Paulo. Revista Brasiliense, n. 28,1955-1964. Bimestral.

CHAVANTES, A. P. A consolidação do setor bancário em São Paulo na década de 1920. 2004. Tese (douturado) Instituto de Economia- Universidade Estadual de Campinas, Campinas, 2004.

COSTA, E. V. Da monarquia à república: momentos decisivos. São Paulo: UNESP, 2007.

CURI, L. F. B. Rui Barbosa e as ideias econômicas: entre teoria e conjuntura. Informações FIPE, n. 418, p. 45, 2015.

DEAN, W. A industrialização de São Paulo. São Paulo: Difel, 1971.

DELFIM NETTO, A. O problema do café no Brasil. São Paulo: UNESP, 2009.

DOMINGUES NETO, H. Navegando o Mogi-Guaçu: a agroexportação cafeeira no Oeste Paulista e a formação de um mercado interno regional,(1883-1903). São Paulo: UNESP, 2009.

FALEIROS, R. N. Fronteiras do café: fazendeiros e colonos no interior paulista (1917-1937).São Paulo: EDUSC; FAPESP, 2010.

FISHLOW, A. Origens e consequências da substituição de importação no Brasil. Estudos Econômicos. v.2, n.6, p. 7-76, 1972

FONSECA, P. C. D. Gênese e precursores do desenvolvimentismo no Brasil. Pesquisa 8 Debate, v. 15, n. 2(26), p. 225-256, 2004.

FONSECA, P. C. D.; MOLLO, M. L. R. Metalistas e papelistas no Brasil: origens teóricas e antecedentes do debate entre monetaristas e estruturalistas no Brasil. Nova Economia, v. 22,n. 2, p. 203-233, maio/ago. 2012.

FRANCO, G. H. B. A primeira década republicana. In: ABREU, M. P. (org.). A ordem do progresso: cem anos de política econômica republicana, 1889-1989. Rio de Janeiro: Campus, 1989.

FRANCO, G. H. B.; LAGO, L. A. C. O processo econômico. In: SCHWARCZ, L. M. A abertura para o mundo: 1889-1930. Rio de Janeiro: Objetiva, 2012.

FRANCO, M. S. C. Homens liures na ordem escravocrata. São Paulo: Unesp, 1997.

FURTADO, C. Formação econômica do Brasil. São Paulo: Companhia Editora Nacional, 2000. 
HABER, S. Industrial concentration and the capital markets: a comparative study of Brazil, Mexico, and the United States, 1830-1930. The Journal of Economic History, v. 51, n. 3,p. 559-580, 1991.

HANLEY, A. G. Native capital: financial institutions and economic development in Sao Paulo, Brazil, 1850-1920. California: Stanford University, 2005.

IBGE. Séries estatísticas retrospectivas. $2^{\mathrm{a}}$ ed. Rio de Janeiro: IBGE, 1990.

IPEA. Democracia participativa: mais de 5 milhões de pessoas ajudaram a formular políticas públicas no Brasil. Desafios do Desenvolvimento, ano 8, n. 65, p. 64-67, 2011.

LAEMMERT, E.; LAEMMERT, H. Almanak administrativo, mercantil e industrial da Corte e Província do Rio de Janeiro. Rio de Janeiro: Henrique Laemmert, 1882; 1889. Disponível em: http://objdigital.bn.br/acervo_digital/div_periodicos/almanak/almanak.htm. Acesso em: 19 jul. 2018.

LENZ, M. H. A crise argentina de 1890: dívida e instabilidade externa. Análise Econômica, v.28, n. 54, p. 225-248, set. 2010.

LEVY, M. B. História da bolsa de valores do Rio de Janeiro. Rio de Janeiro: IBMEC, 1977.

LEVY, M. B. A indústria do Rio de Janeiro através de suas sociedades anônimas. Rio de Janeiro: Ed. UFRJ, 1994.

LOBO, M. E. L. O encilhamento. Revista Brasileira do Mercado de Capitais, v. 2, n. 5, p. 261301, 1976.

LOPES, L. S. Uma economia em transição: a economia e a alocação de riqueza na antiga vila de São Sebastião do Ribeirão Preto, década de 1870. História Econômica 8 História de Empresas, v. 10, n. 2, p. 63-104, 2007.

LOPES, L. S. A economia e a alocação de riqueza bruta em Ribeirão Preto, 1889-1900. História Econômica \& História de Empresas, v. 19, n. 1, p. 59-94, 2016.

MARCONDES, R. L.; HANLEY, A. G. Bancos na transição republicana em São Paulo: o financiamento hipotecário (1888-1901). Estudos Econômicos, v. 40, n. 1, p. 103-131, 2010.

MELLO, J. M. C. O capitalismo tardio. Campinas: Facamp/Editora da UNESP, 2009.

MELLO, Z. M. C. Metamorfoses da riqueza: São Paulo, 1845-1895. São Paulo: Hucitec, 1990.

MITCHELL, B. R. International historical statistics: Europe, 1750-2005. 6th ed. Houndmills: Palgrave Macmillan, 2007.

MILLIET, S. Roteiro do café e outros ensaios: contribuição para o estudo da história econômica e social do Brasil. 4. ed. São Paulo: HUCITEC/INL, 1982.

MORAES, M. L. P. M. Atuação da firma Theodor Wille $\mathcal{E}$ Cia. no mercado cafeeiro do Brasil, 1844-1918. 1988. Tese (Doutorado) - Faculdade de Filosofia, Letras e Ciências Humanas, Universidade de São Paulo, São Paulo, 1988. 
OLIVEIRA, M. F. Cultura de consumo e indústria na São Paulo da Belle Époque (1890-1915). História Econômica \& História de Empresas, v. 17, n. 1, 2014.

PASSANANTI, T.; GERBER, J. Consecuencias económicas de los regímenes financieros: una nueva perspectiva de las políticas bancarias de México y Brasil, 1890-1910. América Latina en la Historia Económica, v. 22, n. 1, p. 35-58, 2015.

PEREIRA, M. A. F. Comissário de café no porto de Santos: 1870-1920. 1980. Dissertação(Mestrado) - Faculdade de Filosofia, Letras e Ciências Humanas, Universidade de São Paulo, São Paulo, 1980.

PERISSINOTTO, R. M. Classes dominantes e hegemonia na República Velha. Campinas: Unicamp, 1994.

PEROSA, R. Comércio e financiamento na lavoura de café de São Paulo no inicio do século. Revista de Administração de Empresa, v. 20, n. 1, p. 63-78, 1980.

PETRONE, M. T. S. O desprezado "ciclo do açúcar" paulista. In: ODALIA, N.; CALDEIRA, J. R. C. História do Estado de São Paulo/ a formação da unidade paulista, v. 2, São Paulo: UNESP, 2010.

PIMENTA, D. J.; ELEUTÉRIO, A. B.; CARAMURU, H. As ferrovias em Minas Gerais. Belo Horizonte: SESC, [s.d.].

SAES, D. A Contestação à Ordem Monárquica no Brasil. Campinas, SP: IFCH/Unicamp, 1992, mimeo. (Col. Primeira Versão, nº 49).

SAES, F. A. M. As ferrovias de São Paulo, 1870-1940. São Paulo: HUCITEC/INL, 1981.

SAES, F. A. M. A grande empresa de serviços públicos na economia cafeeira. São Paulo: Hucitec, 1986a.

SAES, F. A. M. Crédito e bancos no desenvolvimento da economia paulista, 1850-1930. São Paulo: IPE/USP, 1986b.

SAES, F. A. M. Crédito e desenvolvimento em economias agroexportadoras: o caso de São Paulo (1850-1930). Revista do Instituto de Estudos Brasileiros, São Paulo, n. 29, p.29-47, 1988.

SAES, F. A. M. Estradas de ferro e diversificação da atividade econômica na expansão cafeeira em São Paulo, 1870-1900. In: SZMRECSÁNYI, T.; LAPA, J. R. A. (org.). História econômica da indepedência e do império. São Paulo: Hucitec/ABPHE/Edusp / Imprensa Oficial, 2002. p.177-196.

SALOMÃO, I. C. As origens do desenvolvimentismo brasileiro e suas controvérsias: notas sobre o debate historiográfico. In: ENCONTRO NACIONAL DE ECONOMIA POLÍTICA, 22., 2017, Campinas. Anais eletrônicos [...]. Campinas: Instituto de Economia- Universidade Estadual de Campinas, 2017.

SAMPER, M.; FERNANDO, R. Historical statistics of coffee production and trade from 1700 to 1960. In: CLARENCE-SMITH, W. G.; TOPIK, S. The global coffee economy in Africa, Asia and Latin America, 1500-1989. New York: Cambridge Univ. Press, 2003. 
SCHULZ, J. A crise financeira da Abolição. 2. ed. São Paulo: Edusp, 2013.

SILVA, G. P. Uma dinastia do capital nacional: a formação da riqueza dos Lacerda Franco e a diversificação na economia cafeeira paulista (1803-1897). 2011. Tese (Doutorado) - Instituto de Economia, Universidade Estadual de Campinas, Campinas, 2011.

SILVA, G. P. O predomínio das casas estrangeiras sobre a exportação cafeeira em Santos no século XIX. América Latina en la Historia Económica, v. 22, n. 3, p. 213-246, 2015 a.

SILVA, G. P. As brechas ao capital nacional: a liderança da casa J. F. de Lacerda E 3 Cia. sobre a exportação cafeeira em Santos na década de 1880. Economia e Sociedade, Campinas, v. 24, n. 3, p. 541-571, dez. 2015b.

SILVA, S. Expansão cafeeira e origens da indústria no Brasil. $8^{a}$ ed. São Paulo: Alfa-ômega, 1995.

STEIN, S. J. Origens e evolução da indústria têxtil no Brasil: 1850/1950. Rio de Janeiro: Campus, 1979.

STEIN, S. Vassouras: um município brasileiro do café, 1850-1900. Rio de Janeiro: Nova Fronteira, 1990.

SUZIGAN, W. Indústria Brasileira: origem e desenvolvimento. São Paulo: Hucitec/Unicamp, 2000.

TANNURI, L. A. O encilhamento. São Paulo: Hucitec, 1981.

TAUNAY, A. E. O encilhamento: cenas contemporâneas da bolsa do Rio de Janeiro em 1890, 1891 e 1892. São Paulo: Melhoramentos, 1923.

TRINER, G. British Banking in Brazil during the First Republic. Locus, v. 20, n. 2, p. 153-175, 2014.

TRINER, G.; WANDSCHNEIDER, K. The baring crisis and the Brazilian encilhamento, 18891891: an early example of contagion among emerging capital markets. Financial History Review,v.12, n. 2, p. 199-225, 2005.

VERONA, A. F. O mundo é nossa Pátria: a trajetória dos imigrantes operários têxteis de Schio que fizeram de São Paulo e do Bairro do Brás sua temporária morada, de 1891 a 1895. 1999. Tese (Doutorado) - Universidade de São Paulo, São Paulo, 1999.

VERSIANI, F. R. Industrialização e economia de exportação: a experiência brasileira antes de 1914.Revista Brasileira de Economia, v. 34, n. 1,p. 3-40, 1980.

VILlELA, A. A. Política comercial e importações na Primeira República: 1889-1930. 1993. Dissertação (Mestrado)- Departamento de Economia, PUCRio, Rio de Janeiro, 1993.

Recebido em: 13/07/2017. Aceito em: 10/12/2017.

(cc) BY 